2006-01-01

\title{
Apoptosis is Initiated in Human Keratinocytes Exposed to Signalling Factors from Microbeam Irradiated Cells
}

\author{
Fiona Lyng \\ Technological University Dublin, fiona.lyng@tudublin.ie \\ Paula Maguire \\ Technological University Dublin
}

A. Kilmurray

Technological University Dublin

See next page for additional authors

Follow this and additional works at: https://arrow.tudublin.ie/radart

\section{Recommended Citation}

Lyng, F. et al. (2006) Apoptosis is Initiated in Human Keratinocytes Exposed to Signalling Factors from Microbeam Irradiated Cells. International Journal of Radiation Biology, Vol. 82, no.6, pp.393-399. doi:10.1080/09553000600803904

This Article is brought to you for free and open access by the Radiation and Environmental Science Centre at ARROW@TU Dublin. It has been accepted for inclusion in Articles by an authorized administrator of ARROW@TU Dublin. For more information, please contact arrow.admin@tudublin.ie, aisling.coyne@tudublin.ie, gerard.connolly@tudublin.ie.

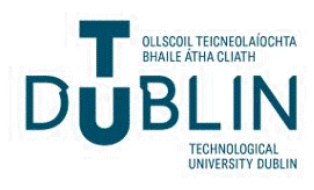




\section{Authors}

Fiona Lyng, Paula Maguire, A. Kilmurray, Carmel Mothersill, C. Shao, M. Folkard, and K. Prise 


\section{Apoptosis is initiated in human keratinocytes exposed to signalling factors from microbeam irradiated cells}

Lyng FM ${ }^{\mathrm{a}, 1}$, Maguire $\mathrm{P}^{\mathrm{a}}$, Kilmurray $\mathrm{N}^{\mathrm{a}}$, Mothersill $\mathrm{C}^{\mathrm{a}, 2}$, Shao $\mathrm{C}^{\mathrm{b}}$, Folkard $\mathrm{M}^{\mathrm{b}}$ and Prise $\mathrm{KM}^{\mathrm{b}}$

${ }^{a}$ Radiation and Environmental Science Centre, Focas Institute, Dublin Institute of Technology, Kevin St, Dublin 8, IRELAND

${ }^{\mathrm{b}}$ Cell and Molecular Biophysics Group, Gray Cancer Institute, Mount Vernon Hospital, Northwood, UK

Running Head: $\quad$ Bystander factor induced apoptosis in microbeam irradiated cells Keywords: $\quad$ Radiation, Bystander Effects, Cell Signalling, Apoptosis

${ }^{1}$ Person to whom all correspondence should be sent:

Dr Fiona M Lyng

Radiation and Environmental Science Centre

Focas Institute

Dublin Institute of Technology

Kevin St

Dublin 8

IRELAND

Email: fiona.lyng@dit.ie

${ }^{2}$ Present address: Medical Physics \& Applied Radiation Sciences, McMaster University, Hamilton, Ontario, Canada 


\begin{abstract}
Purpose: There is now no doubt that bystander signalling from irradiated cells occurs and causes a variety of responses in cells not targeted by the ionising track. However, the mechanisms underlying these processes are unknown and the relevance to radiotherapy and risk assessment remains controversial. Previous research by our laboratory has shown bystander effects in a human keratinocyte cell line, HPV-G cells, exposed to medium from $\gamma$ irradiated HPV-G cells. The aim of this work was to investigate if similar mechanisms to those identified in medium transfer experiments occurred in these HPV-G cells when they are in the vicinity of microbeam irradiated cells. Demonstration of a commonality of mechanisms would support the idea that the process is not artifactual.

Materials and Methods: HPV-G cells were plated as two separate populations on mylar dishes. One population was directly irradiated using a charged particle microbeam (1 - 10 protons). The other population was not irradiated. Bystander factor induced apoptosis was investigated in both populations following treatment by monitoring the levels of reactive oxygen species and mitochondrial membrane potential using fluorescent probes. Expression of the anti-apoptotic protein, bcl-2, and cytochrome c were determined, as well as apoptosis levels.

Results: Microbeam irradiation induced increases in reactive oxygen species and decreases in mitochondrial membrane potential at 6 hours post exposure, increased expression of bcl-2 and cytochrome c release at 6.5 hours and increased apoptosis at 24 hours.
\end{abstract}


Conclusion: This study shows that similar bystander signalling pathways leading to apoptosis are induced following microbeam irradiation and following medium transfer. This demonstrates that the mechanisms involved are common across different radiation qualities and conditions and indicates that they may be relevant in vivo. 


\section{Introduction}

There has been considerable interest recently in non-targeted effects of radiation that cannot be attributed to direct DNA damage. Recent research has shown that low doses of ionising radiation can cause a "bystander effect", where radiation damage occurs in cells not directly irradiated (see reviews; Mothersill and Seymour 2003, Lorimore et al, 2003, Little 2003, Morgan 2003).

Studies with very low doses of $\alpha$ particles have shown increases in the number of sister chromatid exchanges (SCE) (Nagasawa and Little 1992, Deshpande et al, 1997), chromosomal aberrations (Lorimore et al, 1998) and activation of stress inducible signalling pathways (Azzam et al, 1998, 2001, 2003) in considerably more cells than would have been traversed by an $\alpha$ particle.

Microbeams, which allow the targeting of individual cells or subcellular locations within a population with a charged particle beam, have become useful tools in the study of radiation induced bystander effects. Microbeam studies have shown that effects of single cell irradiation are not limited to the exposed cell but affect other cells in the vicinity. Micronucleus formation and apoptosis (Prise et al, 1998, Belyakov et al, 2001, 2003), mutation (Zhou et al, 2000, 2001) and oncogenic transformation (Sawant et al, 2001) have all been shown in cells distant from the target cell.

Medium transfer experiments have shown that bystander effects may be mediated by damage signals released into the culture medium by irradiated cells. Non-irradiated cells incubated with conditioned medium from irradiated cells have shown similar effects to the directly irradiated cells. Mothersill and Seymour (1997, 1998) reported that cell death was induced in unirradiated cells treated with medium from directly irradiated 
epithelial cells. This was further shown to be associated with early apoptotic events such as calcium fluxes, loss in mitochondrial membrane permeability and the induction of reactive oxygen species (ROS) (Lyng et al, 2000, 2002). Lehnert et al (1997) and Narayanan et al (1997) also used medium transfer experiments to show that extracellular factors including ROS were released by $\alpha$ particle irradiated cells leading to increased SCE in nonirradiated cells. Conditioned medium from $\alpha$ particle irradiated cells has also been shown to stimulate proliferation in nonirradiated cells (Iyer et al, 2000). A recent study by Suzuki et al (2004) demonstrated that cells irradiated with $\alpha$ particles released medium borne factors which induced chromatin damage in bystander cells plated on the other side of a medium filled double mylar dish.

To date the majority of reports on bystander effects have used either direct exposure to high linear energy transfer (LET) helium ions delivered by low fluence sources (Nagasawa and Little 1992), direct irradiation using microbeam approaches (Prise et al, 1998, Zhou et al, 2000, Sawant et al, 2001, Shao et al, 2003) or medium transfer after low LET exposure (Mothersill and Seymour 1997).

Two main models have emerged on the mechanisms of bystander responses; cell - cell communication through gap junctions and secretion of a cytotoxic factor into the medium. The model appears to depend on the cell type used for the experiments and on the way the experiments were performed. Some groups have demonstrated a requirement for gap junctional intercellular communication (GJIC) to mediate a bystander response (Azzam et al, 2001, Shao et al, 2003b) but other groups have shown GJIC not to be involved (Mothersill and Seymour 1997, Lehnert et al, 1997). 
A role for ROS in radiation induced bystander effects has been reported by many groups (Lehnert et al 1997, Azzam et al 2002, Lyng et al 2006). Specifically, nitric oxide, an important signalling molecule, has been shown to induce bystander effects (Matsumoto et al 2000, Shao et al 2001, 2002, 2003a, 2004)

The aim of the present study was to investigate bystander responses following microbeam irradiation in a human keratinocyte cell line (HPV-G cells) which has previously been shown to undergo apoptosis when exposed to medium from $\gamma$ irradiated cells (Lyng et al, 2000, 2002, Maguire et al, 2005). Mitochondrial membrane potential depolarisation, cytochrome c release, bcl-2 expression, induction of reactive oxygen species (ROS) and apoptosis levels were measured in HPV-G cells which were in the vicinity of microbeam irradiated HPVG cells. 


\section{Materials and Methods}

\section{Cell Culture}

Human keratinocytes, HPV-G cells, immortalised with the human papilloma virus (HPV) were originally obtained as a kind gift from Dr. J. Di Paolo, NIH Bethesda (Pirisi et al, 1988). HPV-G cells were cultured in Dulbecco's Modified Eagle Medium (DMEM) : F12 (1:1) medium (Sigma, Dorset, U.K.) containing, 10\% fetal bovine serum (Gibco, Irvine, U.K.), 1\% penicillin-streptomycin solution 1000 IU (Gibco, Irvine, U.K.), 2mM L- glutamine (Gibco, Irvine, U.K.) and $1 \mu \mathrm{g} / \mathrm{ml}$ hydrocortisone (Sigma, Dorset, U.K.) Cells were maintained in an incubator at $37^{\circ} \mathrm{C}$, with $95 \%$ humidity and $5 \% \mathrm{CO}_{2}$. Subculture was routinely performed when cells were $80-100 \%$ confluent, using a 1:1 solution of $0.25 \%$ trypsin and $1 \mathrm{mM}$ versene (Sigma, Dorset, U.K.) at $37^{\circ} \mathrm{C}$.

\section{Microbeam irradiation}

For microbeam experiments, plateau phase cells were seeded into specially designed dishes (Folkard et al, 1997) consisting of a $34 \mathrm{~mm}$ diameter base composed of a $4 \mu \mathrm{m}$ thick mylar membrane. Two areas of the dish diagonally opposed to each other had been pretreated with $1 \mu \mathrm{g} / \mathrm{ml}$ CellTak adhesive (Becton Dickinson, Oxford, U.K.). Each area was about $5 \mathrm{~mm}$ in diameter. Cells were seeded $16 \mathrm{~h}$ prior to irradiation to allow full attachment. Typically cells were seeded at a density to allow 600-800 cells in each area of the dish. One hour prior to irradiation cells were incubated with $1 \mu \mathrm{M}$ Hoechst 33258 (Molecular Probes, Leiden, The Netherlands). At the time of irradiation the cell culture medium was replaced with fresh medium containing $20 \mathrm{mM}$ 4-(2-hydroxyethyl)-1piperazineethanesulfonic acid (HEPES) (Sigma, Dorset, U.K.) and irradiation was 
performed at room temperature. All the cells in one area of the dish had exact numbers of 3.2 $\mathrm{MeV}$ protons delivered through the centre of the cell nucleus. Details of the automatic cell finding and imaging system are described in Folkard et al (1997). The cells in the unirradiated area of the dish were bystander cells. The irradiation procedure typically took around 10 min after which fresh medium was added to the cells and incubation continued at $37^{\circ} \mathrm{C}$ for 6 or 24 hours prior to scoring. Control cells were sham irradiated by incubating with $1 \mu \mathrm{M}$ Hoechst 33258 (Molecular Probes, Leiden, The Netherlands) as before and scanning, finding and following the same number of cells as in the irradiated dishes but without actual irradiation.

\section{Measurement of mitochondrial membrane potential}

Mitochondrial membrane potential was determined using rhodamine 123, a green fluorescent dye that accumulates in active mitochondria with high membrane potential. Cultures were washed twice with a buffer containing $130 \mathrm{mM} \mathrm{NaCl}, 5 \mathrm{mM} \mathrm{KCl}, 1 \mathrm{mM}$ $\mathrm{Na}_{2} \mathrm{HPO}_{4}, 1 \mathrm{mM} \mathrm{CaCl} 2,1 \mathrm{mM} \mathrm{MgCl}$ and $25 \mathrm{mM}$ HEPES (pH 7.4). Cells were loaded with $5 \mu \mathrm{M}$ Rhodamine 123 (Sigma, Dorset, U.K.) for $30 \mathrm{~min}$ in the buffer at $37{ }^{0} \mathrm{C}$. Subsequently, the cultures were washed three times with buffer. Fluorescence images were recorded using a Zeiss Axioskope epifluorescence microscope with a BP 450-490 nm excitation filter and LP515 emission filter (Carl Zeiss Ltd, Welwyn Garden City, U.K.) and a cooled charge coupled device (CCD) camera system (Photonic Science, UK). The mean fluorescence intensity (or mean grey value) was determined using the software package, NIH Image (National Institutes of Health, USA). 


\section{Measurement of reactive oxygen species}

Induction of reactive oxygen species was measured using 2,7 - dichlorofluorescin diacetate (DCF-DA) (Sigma, Dorset, U.K.). Once inside a cell, the acetate group is cleaved by cellular esterases leaving dicholorofluorescein which emits green fluorescence when oxidized by the reactive oxygen species, hydrogen peroxide and nitric oxide. Cultures were washed twice with a buffer containing $130 \mathrm{mM} \mathrm{NaCl}, 5 \mathrm{mM} \mathrm{KCl}, 1 \mathrm{mM}$ $\mathrm{Na}_{2} \mathrm{HPO}_{4}, 1 \mathrm{mM} \mathrm{CaCl} 2,1 \mathrm{mM} \mathrm{MgCl}$ and $25 \mathrm{mM}$ HEPES (pH 7.4). Cells were loaded with $5 \mu \mathrm{M}$ 2,7 DCF-DA for $30 \mathrm{~min}$ in the buffer at $37{ }^{0} \mathrm{C}$. Subsequently, the cultures were washed three times with buffer. The cells were then returned to the incubator for 30 mins and washed once more prior to scoring. Fluorescence images were recorded using a Zeiss Axioskope epifluorescence microscope with a BP 450-490 nm excitation filter and LP515 emission filter (Carl Zeiss Ltd, Welwyn Garden City, U.K.) and a cooled CCD camera system (Photonic Science, UK). The mean fluorescence intensity (or mean grey value) was determined using the software package, NIH Image (National Institutes of Health, USA).

\section{Immunocytochemistry}

Following the fluorescence measurements as described above (ie. approx 6.5 hours after microbeam irradiation), the cells were washed twice in phosphate buffered saline (PBS) to remove any debris and then fixed in $10 \%$ buffered formalin. The mylar on which the cells were attached was removed from the microbeam dish and adhered to a glass slide with the cells facing upwards. The slides were marked to indicate the irradiated and 
bystander areas. The slides were immersed in PBS in plastic coplin jars and transported back to Dublin, stored at $4^{\circ} \mathrm{C}$ and assayed within 48 hours. Immunocytochemical analysis was performed using the Strepavidin Peroxidase method for cell culture using the Vectastain ABC kits (Vector Laboratories, UK). The primary antibody, mouse monoclonal, anti-Bcl-2 (Dako, Denmark) or anti-cytochrome c (Dako, Denmark) was applied for one hour (1:50 and 1:250 dilution respectively). Biotinylated anti-mouse reagent was then added to the cells for 30 minutes followed by Strepavidin Peroxidase for a further 30 minutes, with a wash in PBS in between each step. The chromagen, $0.02 \%$ DAB (Sigma, Dorset, U.K.) was then added for 10 minutes in darkness and washed off in distilled water. Cells were then counterstained with Harris haematoxylin and mounted with glycergel. A negative control, where no primary antibody was added was included in each experimental run. Positive staining was determined by brown staining in the cytoplasm. Numbers of cells positive for bcl-2 or cytochrome c were scored blind in both direct and bystander areas on each of three replicate slides and expressed as the percentage of the total cells counted (approx. 400 - 500 cells were counted in each area).

\section{Quantification of apoptosis}

Twenty four hours after microbeam irradiation, the cells were washed twice in PBS to remove any debris and then fixed in $10 \%$ buffered formalin. The mylar was removed and adhered to a glass slide as described above. The slides were transported back to Dublin immersed in PBS in plastic coplin jars, stored at $4^{0} \mathrm{C}$ and assayed within 48 hours. The cells were stained for 15 mins with $1 \mu \mathrm{g} / \mathrm{ml}$ Propidium Iodide (Sigma, Dorset, U.K.) to visualise the nuclei. Slides were scored for the presence of apoptotic cells using a Zeiss 


\begin{abstract}
Axioplan epiflourescence microscope equipped with BP546/12 nm excitation filter and LP590nm emission filter (Carl Zeiss Ltd, Welwyn Garden City, U.K.). Cells were defined as apoptotic if they displayed evidence of two or more of the following; cell volume shrinkage and pycnotic nucleus (chromatin condensation), nuclear fragmentation and formation of apoptotic bodies (Kerr and Harmon 1991). Numbers of apoptotic cells were scored blind in both direct and bystander areas on each of three replicate slides and expressed as the percentage of the total cells counted (approx. 500 cells were counted in each area).
\end{abstract}

\title{
Statistical analysis
}

Microscope and detector parameters were standardised to allow quantitative comparisons of the relative fluorescence intensity of the cells between groups. All measurements are presented as mean values \pm S.E. of 3 independent experiments with 3 replicate dishes per measurement. Significance of differences was determined by a student's unpaired t-test and the differences were considered significant if $\mathrm{p} \leq 0.05$. 


\section{Results}

A significant reduction in rhodamine 123 fluorescence, indicating mitochondrial membrane potential depolarisation, was observed in HPV-G cells 6 hours after direct microbeam irradiation (figure 1). Cells that were not directly irradiated but were in the same dish (bystander cells) also showed a similar significant reduction in fluorescence (figure 1).

A significant increase in DCF-DA fluorescence, indicating an increase in ROS, was observed in HPV-G cells 6 hours after direct microbeam irradiation (figure 2). Cells in another area of the same dish (bystander cells) also showed a significant increase in fluorescence (figure 2).

Both the directly irradiated cells and the bystander cells showed increased expression of bcl-2 6.5 hours after microbeam irradiation (table I). Similarly increased levels of cytochrome c were observed 6.5 hours after microbeam irradiation in both the directly irradiated cells and the bystander cells (table I).

HPV-G cells showed increased apoptosis 24 hours after direct microbeam irradiation (figure 3). Cells that were not directly irradiated but were in the same dish (bystander cells) also showed a similar increase in apoptosis levels (figure 3).

For all endpoints measured, there was no significant difference between the effect in the directly irradiated cells and the bystander cells. Similarly there was no significant difference between the effect following irradiation with 1 or 10 protons to the directly exposed cells. 


\section{Discussion}

This study has shown a significant reduction in mitochondrial membrane potential and a significant increase in ROS in both directly irradiated and bystander HPV-G cells 6 hours after microbeam irradiation. Increased bcl-2 expression and cytochrome c release, after approx 6.5 hours, and increased apoptosis, after 24 hours, were also observed. No significant differences were observed between the effects of different doses.

These results are very similar to those previously reported for HPV-G cells exposed to medium from $\gamma$ irradiated cells (Lyng et al, 2000, 2002, Maguire et al, 2005). This finding is important as it shows the mechanisms are similar for medium transfer and for microbeam irradiation and therefore more likely to be universal.

The findings from this study and from previous studies (Lyng et al, 2000, 2002, Maguire et al, 2005) have shown that early apoptotic events, such as mitochondrial membrane potential depolarisation, induction of ROS, expression of bcl-2 and release of cytochrome $\mathrm{c}$ are induced in normal human keratinocytes either exposed to medium from $\gamma$ irradiated cells or in the vicinity of microbeam irradiated cells. The effects observed appear to be independent of the dose or number of protons delivered to the irradiated cells. A medium borne factor is likely to be involved in both cases. It is unlikely that gap junctional communication is involved in the medium transfer approach and in the present microbeam study the directly irradiated cells and the bystander cells were two distinct populations separated by on average $6 \mathrm{~mm}$.

Most of the studies on bystander effects have used either direct exposure to low fluences of $\alpha$ particles, direct irradiation using microbeam approaches or medium transfer after 
low LET exposure. There have been very few reports on the LET dependence of the bystander effect. Hickman et al (1994) observed a bystander response, evidenced by increased p53 expression, in rat lung epithelial cells exposed to low fluences of $\alpha$ particles. No increase was seen in cells exposed to similar doses (less than $10 \mathrm{cGy}$ ) of X-rays, indicating the existence of a relatively higher damage threshold for sparsely ionizing radiation. Shao et al (2002, 2003b) reported an LET dependent induction of micronuclei and cell proliferation in human neoplastic epithelial cells. High LET (100 $\mathrm{keV} / \mu \mathrm{m}$ ) carbon-ion irradiation was found to be more efficient at inducing the mediummediated bystander effect than low LET $(13 \mathrm{keV} / \mu \mathrm{m})$ carbon-ion irradiation. Further studies by the same group compared the bystander responses in primary human fibroblasts individually targeted by a high LET heavy particle microbeam of ${ }^{40} \mathrm{Ar}(1260$ $\mathrm{keV} / \mu \mathrm{m})$ or ${ }^{20} \mathrm{Ne}(380 \mathrm{keV} / \mu \mathrm{m})$ (Shao et al, 2003b). An increase in micronuclei was observed independent of the LET and the number of particles delivered to the targeted cells. Previous studies by our group has shown increased apoptosis in human keratinocytes exposed to a medium borne factor from cells irradiated with low LET $\gamma$ rays (Lyng et al, 2000, 2002, Maguire et al, 2005). The protons used in the present study (3.2 $\mathrm{MeV}$ with an LET of $\sim 13 \mathrm{keV} / \mu \mathrm{m}$ ) are essentially low LET and importantly, the degree of bystander responses observed was similar to that obtained with $\gamma$-rays.

An important observation from these studies is that the level of effect is the same regardless of whether cells were directly exposed or were neighboring non-targeted bystander cells. This agrees with other studies showing that at least after low dose exposure, the bystander response predominates the overall effect (Schettino et al, 2003, Seymour and Mothersill 2000). 


\title{
References
}

Azzam EI, de Toledo SM, Gooding T, Little JB. 1998. Intercellular communication is involved in the bystander regulation of gene expression in human cells exposed to very low fluences of alpha particles. Radiation Research 150: 497-504

\begin{abstract}
Azzam EI, de Toledo SM, Little JB. 2001. Direct evidence for the participation of gap junction-mediated intercellular communication in the transmission of damage signals from alpha -particle irradiated to nonirradiated cells. Proceedings of the National Academy of Sciences U.S.A. 98: 473-478
\end{abstract}

\begin{abstract}
Azzam EI, de Toledo SM, Spitz DR, Little JB. 2002. Oxidative metabolism modulates signal transduction and micronucleus formation in bystander cells from alpha-particleirradiated normal human fibroblast cultures. Cancer Research 62: 5437-5442
\end{abstract}

\begin{abstract}
Azzam EI, de Toledo SM, Little JB. 2003. Oxidative metabolism, gap junctions and the ionizing radiation-induced bystander effect. Oncogene 22: 7050-7057
Belyakov OV, Malcolmson AM, Folkard M, Prise KM and Michael BD. 2001. Direct evidence for a bystander effect of ionizing radiation in primary human fibroblasts. British Journal of Cancer 84: 674-679


Belyakov OV, Folkard M, Mothersill C, Prise KM, Michael BD. 2003. A proliferationdependent bystander effect in primary porcine and human urothelial explants in response to targeted irradiation. British Journal of Cancer 88: 767-774

Deshpande A, Goodwin EH, Bailey SM, Marrone BL and Lehnert BE. 1997. Alphaparticle-induced sister chromatid exchange in normal human lung fibroblasts: evidence for an extranuclear target. Radiation Research 145: 260-267

Folkard M, Vojnovic B, Hollis KJ, Bowey AG, Watts SJ, Schettino G, Prise KM and Michael BD. 1997. International Journal of Radiation Biology 72: 387-395

Hickman AW, Jaramillo RJ, Lechner JF, Johnson NF. 1994. Alpha-particle-induced p53 protein expression in a rat lung epithelial cell strain. Cancer Research 54: 5797-5800

Iyer R, Lehnert BE and Swensson R. 2000. Factors underlying the cell growth-related bystander responses to alpha particles. Cancer Research 60: 1290-1298

Kerr JFR and Harmon BV. 1991. Definition and incidence of apoptosis. An historical perspective. In: Tomei LD and Cope FO, editors. Apoptosis. The Molecular Basis of Cell Death, New York: Cold Springs Harbour Laboratory, pp 5 - 9 
Lehnert BE, Goodwin EH, Desppande A. 1997. Extracellular factor(s) following exposure to alpha-particles can cause sister chromatid exchanges in normal human cells. Cancer Research 57: 2164-2171

Little JB. 2003. Genomic instability and bystander effects: a historical perspective. Oncogene 22: 6978-6987

Lorimore SA, Coates PJ, Wright EG. 2003. Radiation-induced genomic instability and bystander effects: inter-related nontargeted effects of exposure to ionizing radiation. Oncogene 22: 7058-7069

Lyng FM, Seymour CB, Mothersill C. 2000. Production of a signal by irradiated cells which leads to a response in unirradiated cells characteristic of initiation of apoptosis. British Journal of Cancer 83: 1223-1230.

Lyng FM, Seymour CB, Mothersill C. 2002. Initiation of apoptosis in cells exposed to medium from the progeny of irradiated cells: a possible mechanism for bystanderinduced genomic instability? Radiation Research 157: 365-370

Lyng FM, Maguire P, McClean B, Seymour C, Mothersill C. 2006. The involvement of calcium and MAP kinase signalling pathways in the production of radiation induced bystander effects, Radiation Research (in press) 


\begin{abstract}
Maguire P, Mothersill C, Seymour C and Lyng FM. 2005. Medium from irradiated cells induces dose dependent mitochondrial changes and bcl-2 responses in unirradiated human keratinocytes. Radiation Research 163: 384-390
\end{abstract}

\begin{abstract}
Matsumoto H, Hayashi S, Hatashita M, Shioura H, Ohtsubo T, Kitai R, Ohnishi T, Yukawa O, Furusawa Y, Kano E. 2000. Induction of radioresistance to accelerated carbon-ion beams in recipient cells by nitric oxide excreted from irradiated donor cells of human glioblastoma. International Journal of Radiation Biology 76: 1649-1657
\end{abstract}

Morgan WF. 2003. Non-targeted and delayed effects of exposure to ionizing radiation: I. Radiation-induced genomic instability and bystander effects in vitro. Radiation Research 159: $567-580$

\begin{abstract}
Mothersill C, Seymour C. 1997. Medium from irradiated human epithelial cells but not human fibroblasts reduces the clonogenic survival of unirradiated cells. International Journal of Radiation Biology 71 421-427
\end{abstract}

Mothersill C, Seymour CB. 1998. Cell-cell contact during gamma irradiation is not required to induce a bystander effect in normal human keratinocytes: evidence for release during irradiation of a signal controlling survival into the medium. Radiation Research 149 256-262 


\begin{abstract}
Mothersill C and Seymour CB. 2004. Radiation-induced bystander effects--implications for cancer. Nature Reviews Cancer 4: 158-164
\end{abstract}

\begin{abstract}
Nagasawa H and Little JB. 1992. Induction of sister chromatid exchanges by extremely low doses of alpha particles. Cancer Research 52: $6394-6396$
\end{abstract}

\begin{abstract}
Narayanan PK, Goodwin EH, Lehnert BE. 1997. $\alpha$ particles initiate biological production of superoxide anions and hydrogen peroxide in human cells. Cancer Research 57: $2963-3971$
\end{abstract}

\begin{abstract}
Pirisi L, Creek KE, Doniger J, DiPaolo J. 1988. Continuous cell lines with altered growth and differentiation properties originate after transfection of human keratinocytes with human papillomavirus type 16 DNA. Carcinogenesis. 9: 1573-1579
\end{abstract}

\begin{abstract}
Prise KM, Belyakov OV, Folkard M, and Michael B. 1998. Studies of bystander effects in human fibroblasts using a charged particle microbeam. International Journal of Radiation Biology 74: 793-798
\end{abstract}

\begin{abstract}
Sawant SG, Randers-Pehrson G, Geard CR, Brenner DJ, Hall EJ. 2001. The bystander effect in radiation oncogenesis: I. Transformation in $\mathrm{C} 3 \mathrm{H} 10 \mathrm{~T} 1 / 2$ cells in vitro can be initiated in the unirradiated neighbors of irradiated cells. Radiation Research 155: 397401
\end{abstract}


Schettino G, Folkard M, Prise KM, Vojnovic B, Held KD and Michael BD. 2003. Lowdose studies of bystander cell killing with targeted soft X rays, Radiation Research 160 : $505-511$

Seymour CB, Mothersill C. 2000. Relative contribution of bystander and targeted cell killing to the low-dose region of the radiation dose-response curve. Radiation Research 153: $508-511$.

Shao C, Aoki M, Furusawa Y. 2001. Medium-mediated bystander effects on HSG cells co-cultivated with cells irradiated by X-rays or a $290 \mathrm{MeV} / \mathrm{u}$ carbon beam. Journal of Radiation Research (Tokyo) 42: 305-316

Shao C, Furusawa Y, Aoki M, Matsumoto H, Ando K. 2002. Nitric oxide-mediated bystander effect induced by heavy-ions in human salivary gland tumour cells. International Journal of Radiation Biology 78: 837-844

Shao C, Stewart V, Folkard M, Michael BD and Prise KM. 2003a. Nitric oxide-mediated signaling in the bystander response of individually targeted glioma cells. Cancer Research 63 8437-8442

Shao C, Furusawa Y, Kobayashi Y, Funayama T, Wada S. 2003b. Bystander effect induced by high-LET particles in confluent human fibroblasts: a mechanistic study. FASEB Journal 17: 1422-1427 
Shao C, Aoki M, and Furusawa Y. 2004. Bystander effect in lymphoma cells vicinal to irradiated neoplastic epithelial cells: Nitric oxide is involved. Journal of Radiation Research 45: 97-103

Suzuki M, Zhou H, Geard CR, Hei TK. 2004 Effect of medium on chromatin damage in bystander mammalian cells. Radiation Research 162: 264- 269

Zhou H, Randers-Pehrson G, Waldren CA, Vannais D, Hall EJ and Hei TK. 2000. Induction of a bystander mutagenic effect of alpha particles in mammalian cells. Proceedings of the National Academy of Sciences U.S.A. 97: 2099-2104

Zhou H, Suzuki M, Randers-Pehrson G, Vannais D, Chen G, Trosko JE, Waldren CA, Hei TK. 2001. Radiation risk to low fluences of alpha particles may be greater than we thought. Proceedings of the National Academy of Sciences U.S.A. 98:14410-14415

\section{Acknowledgements}

The authors acknowledge support from Science Foundation Ireland, the Royal Irish Academy, the Royal Society, the Gray Cancer Institute and Cancer Research UK. 


\section{Figure Legends}

Figure $1 \%$ Fluorescence from rhodamine 123 in both directly irradiated and bystander HPV-G cells 6 hours after microbeam irradiation. A decrease in fluorescence levels is indicative of a decrease in mitochondrial membrane potential. $* \mathrm{p}<0.001$

Figure $2 \%$ Fluorescence from 2,7 dichlorofluorescin diacetate in both directly irradiated and bystander HPV-G cells 6 hours after microbeam irradiation. An increase in fluorescence levels is indicative of an increase in reactive oxygen species. $* p<0.001$

Figure $3 \%$ Apoptotic cells in both directly irradiated and bystander HPV-G cells 24 hours after microbeam irradiation. ${ }^{*} \mathrm{p}<0.05, * * \mathrm{p}<0.01$ 
Table I $\%$ HPV-G cells positive for bcl-2 and cytochrome c 6.5 hours following microbeam irradiation. $* \mathrm{p}<0.05, * * \mathrm{p}<0.01, * * * \mathrm{p}<0.005$

\section{$\%$ bcl-2 positive cells \% cytochrome c positive cells}

\begin{tabular}{lcccc}
\hline Dose & Direct & Bystander & Direct & Bystander \\
Control & $2.17 \pm 0.33$ & $1.67 \pm 0.60$ & $1.83 \pm 0.44$ & $2.50 \pm 0.73$ \\
$\mathbf{1}$ proton & $7.17 \pm 0.73 * *$ & $7.00 \pm 0.29 *$ & $13.83 \pm 0.60 * * *$ & $14.17 \pm 0.88 * *$ \\
$\mathbf{1 0}$ protons & $9.00 \pm 0.59 * *$ & $7.67 \pm 1.01 *$ & $15.67 \pm 0.73 * * *$ & $14.33 \pm 0.19 * *$ \\
\hline
\end{tabular}




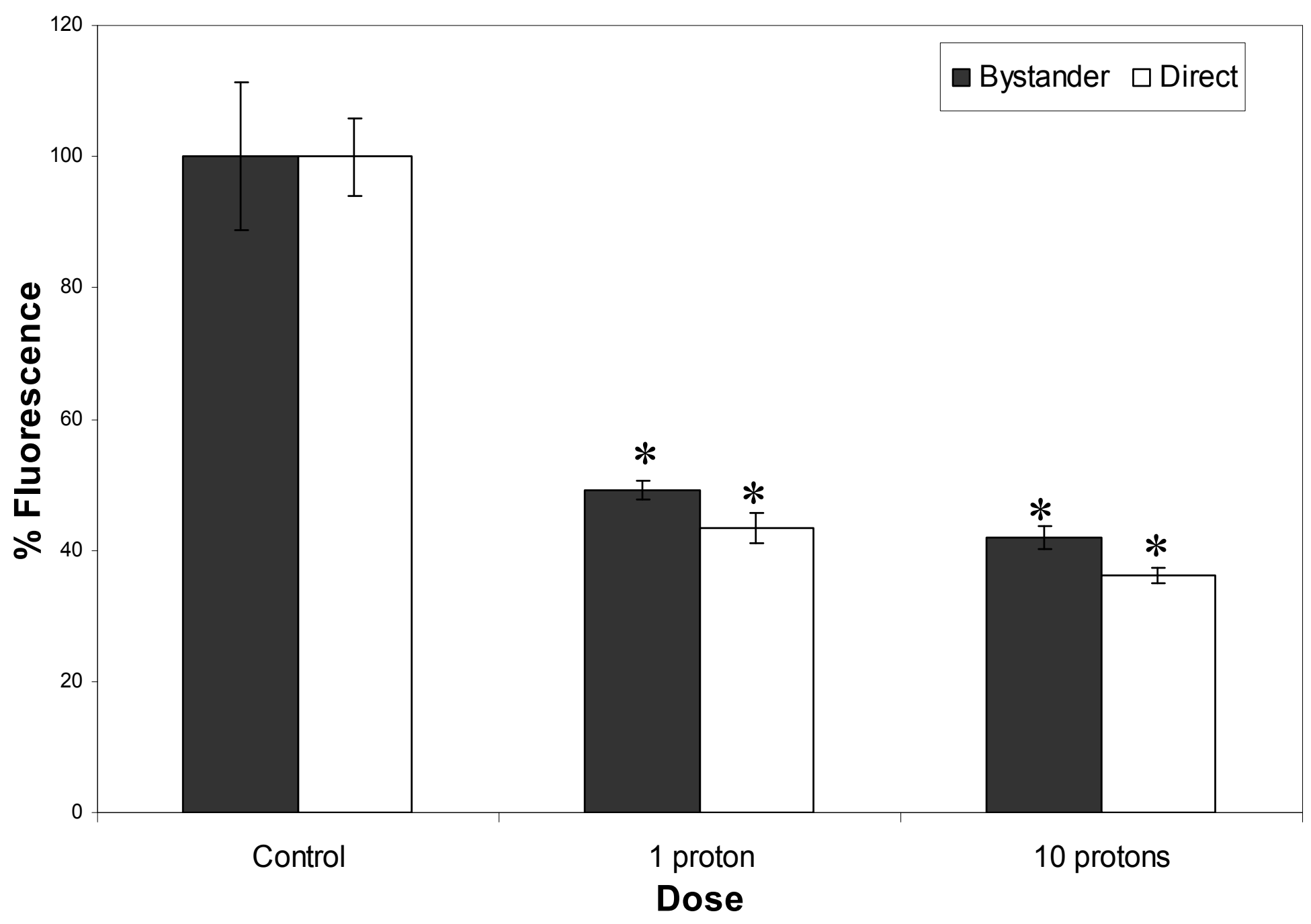

E-mail: ijrb@uhnres.utoronto.ca URL: http://mc.manuscriptcentral.com/ijrb 


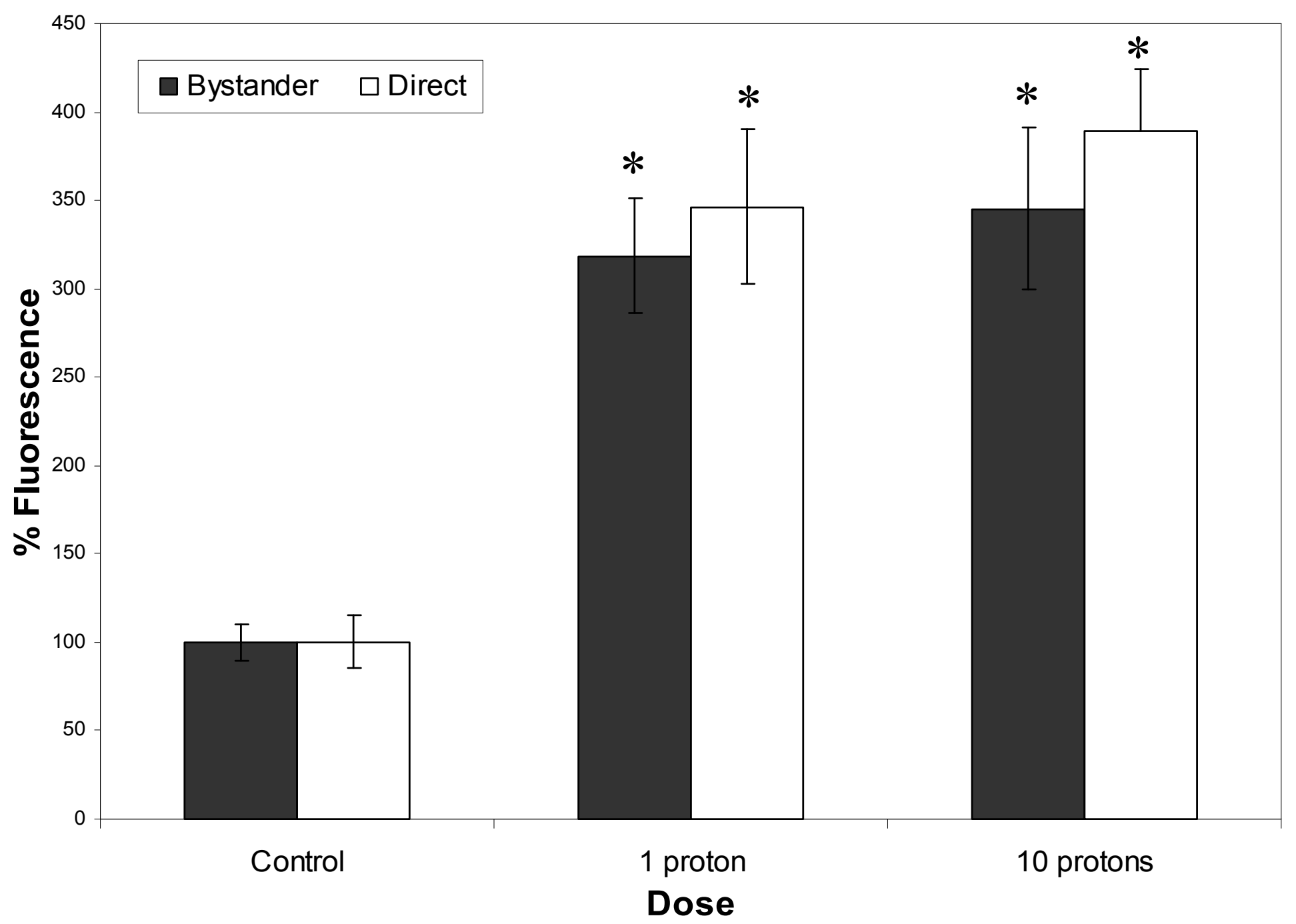

E-mail: ijrb@uhnres.utoronto.ca URL: http://mc.manuscriptcentral.com/ijrb 


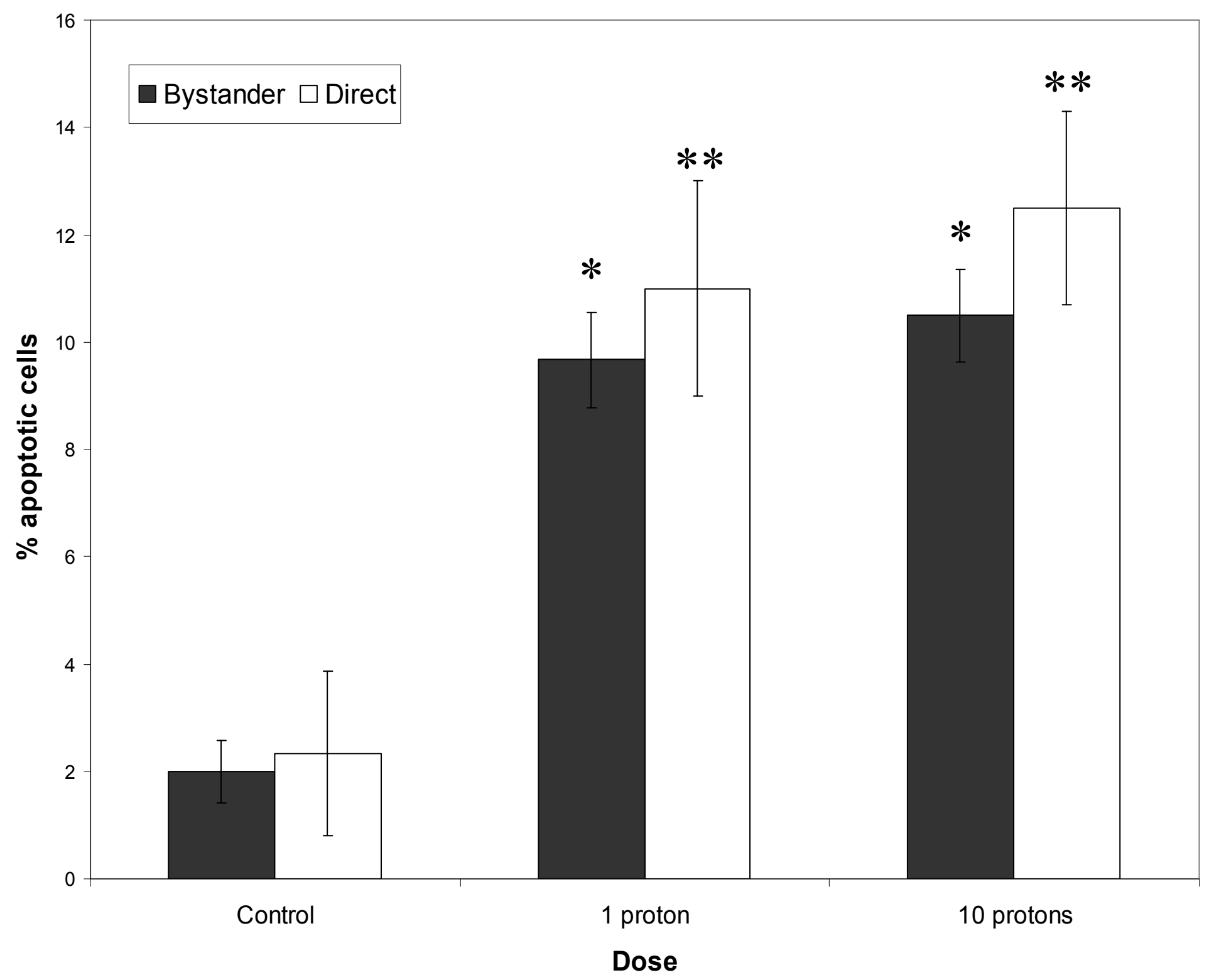

E-mail: ijrb@uhnres.utoronto.ca URL: http://mc.manuscriptcentral.com/ijrb 